\title{
SIMULATION OF COMMUNICATION SITUATIONS IN ENGLISH CLASSES AND THEIR EFFECTIVENESS
}

\author{
Kismetova G.N. \\ Candidate of Pedagogic Sciences, \\ Associate Professor M.Utemisov WKU \\ Republic of Kazakhstan. Uralsk \\ Tastemirova S. D. \\ Master student of M. Utemisov WKU
}

\section{МОДЕЛИРОВАНИЕ СИТУАЦИЙ ОБЩЕНИЯ НА ЗАНЯТИЯХ АНГЛИЙСКОГО ЯЗЫКА И ИХ ЭФФЕКТИВНОСТЬ}

\author{
Кисмтеова Г.Н. \\ Кандидат педагогических наук, \\ доиент ЗКУ им. М.Утемисова \\ г. Уральск, Республика Казахстан \\ Тастемирова С.Д. \\ Магистрант ЗКУ им. М.Утемисова
}

\begin{abstract}
Аннотация. В статье описана методика, которая может стимулировать изучающих английский язык к активным, целеустремленным, реалистичным и относительно сложным действиям на иностранном языке. Цель этой статьи - показать потенциал ситуаций общения для обучения английского языка, дать предложения по выбору, разработке, подготовке, внедрению и дальнейшему развитию ситуаций общения.

Annotation. The article describes a technique that can stimulate English learners to be active, goal-oriented, realistic and relatively challenging in a foreign language. The purpose of this article is to show the potential of communication situations for teaching English, to give suggestions for the selection, development, preparation, implementation and further development of communication situations.

Ключевые слова: ситуации общения, моделирование, коммуникация, учебно-речевая ситуация.

Key words: communication situations, modeling, communication, educational-speech situation.

Communication learning assumes that the learning process is built as a model of the communication process.

As you know, simulation is a tool that can prepare the student for these requirements. Jones names three main elements of modeling:

- the reality of the function,

- simulated environment

- structure.

The reality of a function means that the participants in the simulation accept the assigned and specific role as real and responsibly perform or solve the related functions and tasks. The simulated environment is similar to reality, but safer or less sanctioned than real life situations. Errors or problems in modeling a foreign language have less serious consequences than errors in real life. Structure is another important feature. It is necessary to describe in detail the context, situation, participants and their roles in solving one or more problems. This technology can be applied at various stages of learning a foreign language [4].

Modeling communication situations contributes to the development of skills in speaking and writing expands the vocabulary and linguistic horizons of students of all ages.

For educators, the question arises as to what attributes make communication situations effective and challenging and what are the desired effects of their use. Hyland gives five reasons for using communication situations in teaching foreign languages:

- modeling has a motivating effect, especially because the communicative actions of the participants are purposeful and problem-oriented.

- you contribute to the automation of language skills through frequent repetition of language structures and test actions / communication between participants.

- Simulation allows you to integrate different skills. They often require the application of pragmatic and intercultural competence, as well as general cognitive problem-solving skills.

- Active student participation is achieved by providing all participants with a role with an appropriate function and, thus, mandatory participation in the problem solving process.
\end{abstract}


- As a final argument, Hyland cites a reduction in stress and fear of speaking [3]. Since mistakes and problems are not immediately assessed and corrected, modeling according to Arendt is a "space with little sanctions" for communicative actions [1].

Simulation can also help develop self-reflection skills and increase the objectivity of student and group self-esteem. It should be noted that simulations, if carried out correctly, create an extremely important sense of success in the student of a foreign language, "the ability to communicate", which has a positive effect on the overall motivation of the student. Another important element is the unpredictability and openness of the solution to the problem to be solved in the simulation. Participants face directly the consequences of their actions to solve problems. This provides (with all the structure) a degree of spontaneity and creativity, which is also greater in real communicative action [2].

In this article, I want to consider a situational type of modeling, that is, the creation of situations of verbal communication on a specific topic.

The construction of a communicative learning process will first of all require modeling the situation, as a unit of communication and as a form of its functioning.

The situation is the essential basis for mastering the material at all stages of learning.

To create situations of verbal communication, it is methodologically significant to determine the most typical relationships. Analysis shows that relationships can be "driven" by four main factors:

1. the social status of a person. Status subjects act as representatives of a class, professional, age, territorial groups;

2. his role as a subject of communication. Role - relationships in a specific situation;

3. the activities performed. Relationships that are implemented in joint activities;

4. moral criteria. Moral relationships is fostering a sense of duty, responsibility [7].

The advantage of situational modeling is the fact that it prepares students to communicate in a foreign language in various life circumstances.

Natural speech situations (EPC) serve as a guideline in the organization of training, and the main means are exercises that consolidate the necessary language material (constructions, words, expressions) and educational speech situations. An educational-speech situation (URS) is one of the methods of work, the meaning of which is to recreate a communication situation typical for a teacher's activity in order to include trainees in this activity [6]. In order to bring the conditions of the URS closer to the conditions of real communication and, thus, prepare students for the possible EPCs in their life, it is necessary to determine the features of real communication:

1. real life circumstances;

2. interest of the speakers in the content of the conversation;

3. the need to conduct a conversation in a foreign language, otherwise the information cannot be obtained.

For example, while in a foreign country, a person wants to catch a taxi or a situation in a hospital; he has to address passers-by, ask them questions, listen and understand their answers. The following tasks can be offered here:

1) - Excuse me, where can I get a taxi?

- Most likely you can get a taxi only in Manhattan. Here in Brooklyn you better call a car-service.

- How do I do it?

- You can get a Yellow Pages or call information for any car service number in the area.

2) - Hello! I would like to make an appointment to see a physician.

- Which doctor would you like to see?

- I am applying for the first time, can you recommend a good doctor?

- Yes, sure. Doctor Kim is a good doctor. Would you like to see him?

- Okay.

- What day can you come?

- Wednesday is okay.

- We are all booked up through Friday. The earliest you can see him is on Saturday.

The next opportunity for approaching speech situations to the conditions of real communication is working in pairs. For example, students receive an assignment like this:

"Work in pairs. You want to persuade your classmates to make some small changes to their lifestyle. But ones that will have a significant effect on the environment».

The task of the teacher is to bring the situation closer to real life. With the help of questions suggested by the teacher or stronger students, the conversation on the given material should be in the nature of a discussion and not turn into a story.

Modeling is mainly used at the end of a lesson or at the end of a topic to provide a framework for complex linguistic productive activities. However, modeling can in principle also introduce the topic at the beginning of the lesson. Depending on the volume, they can be prepared and presented within an hour or within a few hours. In principle, simulations are also suitable for assessing language skills, for example as an oral final exam or as a project at the end of a semester.

There are certain requirements for the exercises that the teacher is guided by when proposing a particular situation:

- Exercises should only cover familiar language material; 
- should be carried out not only orally, but also in writing;

- the need to use a method of showing various samples - oral answers, which prevents unnecessary dialogue, "asking" for details and that allows you to form a monologue variety of students' speech;

- availability and feasibility;

- increasing difficulties and regularity;

- variety of exercises, purpose and order of performance [5].

In conclusion, I want to say that modeling is the most important method of scientific knowledge and research today. The modeling method is used in any science, at all stages of scientific knowledge. Also, from the above, we can conclude: the more dialogical speech, monologue, individual work, in pairs, in groups, the use of technical teaching aids and visual aids, that is, as many non-standard forms of lessons as possible, the higher the interest will be student to the subject, the motivation to learn something new, the higher the efficiency of work and the ability of students to work in the classroom.

\section{Список использованной литературы:}

1. Arendt Manfred Simulationen. In: Der Fremdsprachliche Unterricht-Englisch, 1997, c.4-10.

2. Ecke Peter, Problems with pets: A set of simulation-games., 1999, c.42-44.

3. Hyland Ken, Language learning simulations: A practical guide., 1993, c.16-21.

o

лухина Н.В., Тихомирова Е.В. Контроль устного неофициального общения на иностранном языке, ИЯШ. - 1998, c.30.

укова Ю.В., Игровые технологии как условие создания мотивационной основы обучения иностранным языкам. Современные технологии обучения иностранным языкам, 2017, с.45.

ассов Е.И., Стояновский А.М., Ситуация речевого общения как постоянная категория. Иностранные языки, 1989, №2, c.18-22

n

References:

, 1. Arendt Manfred Simulationen. In: Der Fremdsprachliche Unterricht-Englisch, 1997, pp. 4-10.

2. Ecke Peter, Problems with pets: A set of simulation-games., 1999, pp. 42-44.

S 3. Hyland Ken, Language learning simulations: A practical guide., 1993, pp.16-21.

i 4. Jones Ken, Simulations: A handbook for teachers and trainers. London., 1987, pp. 20-25.

$\mathrm{m}$ 5. Elukhina N.V., Tikhomirova E.V. Control of oral unofficial communication in a foreign language, School of Foreign language. - 1998, pp. 30. (In Russian).

1 6. Zhukova Yu.V., Game technologies as a condition for creating a motivational basis for teaching foreign languages. Modern technologies of teaching foreign languages, 2017, pp. 45. (In Russian).

$\mathrm{t}$ 7. Passov E.I., Stoyanovskiy A.M., The situation of speech communication as a permanent category. Foreign languages, 1989, No. 2, pp.18-22. (In Russian).

O

$\mathrm{n}$

$\mathrm{S}$

A

$\mathrm{h}$

a

n

d

b

O

O

k 